\title{
Effects of different amounts of cellulase on the microstructure and soluble substances of cotton stalk bark
}

\author{
Zhaoyong Xie $^{1} \cdot$ Zhongjian Tian $^{1} \cdot$ Shan $\mathrm{Liu}^{1} \cdot \mathrm{Hao} \mathrm{Ma}^{1} \cdot$ Xing-Xiang Ji $^{1} \cdot$ Chuanling $\mathrm{Si}^{1,2}$
}

Received: 23 October 2021 / Revised: 22 November 2021 / Accepted: 24 November 2021 / Published online: 23 January 2022

(c) The Author(s) 2021

\begin{abstract}
There are plant cuticle and complex cell walls on the outer surface of cotton stalk bark (CSB), which reduce the efficiency of liquid penetration of CSB. To increase the permeability of liquids, these barriers need to be broken. Cellulase can selectively hydrolyze cellulose into glucose, and its action conditions are mild. Therefore, cellulase treatment is one of the excellent ways to break the CSB liquid permeation barrier. This experiment studied the effects of different amounts of cellulase treatment on the enzymatic hydrolysis products and surface of CSB. Scanning electron microscopy (SEM) and nano-CT were used to observe the changes in the microscopic morphology of CSB. Ion chromatography and an ultraviolet-visible spectrophotometer were used to determine the dissolution of CSB. The results showed that the cuticle of CSB treated with cellulase was broken, and the cell wall of phloem fibers became thinner, which increased the accessibility of liquid. The content of monosaccharide and lignin in CSB treatment solution increased with the increase of cellulase dosage. Correspondingly, the proportion of polysaccharides on the outer surface of CSB continued to decline and eventually stabilized. These experimental results can provide a reference for improving the permeability of natural fibers and the subsequent treatment effects of biomass products.
\end{abstract}

Keywords Cotton stalk bark $\cdot$ Cellulase $\cdot$ Microstructure $\cdot$ Soluble substance

\section{Introduction}

Cotton is the most abundant cash crops and agriculture products in tropical and sub-tropical countries. Cotton growing areas are distributed all over the world, and the major countries are China, India, USA, Brazil, Uzbekistan, Turkey, Australia, Turkmenistan, Greece, Syria, and Egypt [1]. To obtain high economic benefits, cotton is grown as an annual plant in the world. Cotton brings good benefits to farmers and planting areas. Cottons are also in great demand

Zhongjian Tian

tianzhj@qlu.edu.cn

Xing-Xiang Ji

xxjt78@163.com

$\triangle$ Chuanling Si

sichli@tust.edu.cn

1 State Key Laboratory of Biobased Material and Green Papermaking, Qilu University of Technology (Shandong Academy of Sciences), Jinan 250353, China

2 Tianjin Key Laboratory of Pulp and Paper, Tianjin University of Science and Technology, Tianjin 300457, China for scientific research; because cottons can be applied to the preparation of various materials [2-7]. But many byproducts (cotton stalks or leaves) remain in the field, which may create solid waste disposal problems as well as cause pests and diseases to subsequent cotton crops [8]. The most common way to solve this is to stack and burn the cotton stalks in the farmlands, which creates air pollution [9]. The high-value utilization of cotton stalks not only brings better economic benefits to farmers, but also can reduce resource waste and environmental pollution. As a kind of angiosperm, cotton stalk is similar to poplar, and the fiber morphology of cotton stalk is closer to wood fiber. Compared with wheat straw, cotton stalk has a higher cellulose content but lower ash and pentose. Besides, the chemical compositions of cotton stalk roots, stems, and branches are very similar. Poplar, wheat straw, and cotton stalks are all biomass. Compared with other renewable energy sources, biomass is widely distributed. Therefore, more and more researchers are focusing on the research of biomass [10-22]. As one of the three major components of plant biomass, cellulose has attracted much attention. Cellulose can be used to make paper, paperbased materials, hydrogels, and aerogel [23-39]. Besides, 
cellulose and its derivatives can be applied in the field of electrical materials [40-45]. Cellulose can also be used to produce platform compounds [46-56]. In addition, combining cellulose with other materials can produce a variety of composite materials [57-63]. Cotton stalk has been widely studied as a high-quality raw material to produce biomass products. For example, the economic and environmental cotton stalk was used to produce nanocrystalline cellulose aerogel, and its performance was close to that of cotton producing nanocrystalline cellulose aerogel [64]. The performances of cotton stalk bark fiber prepared by the combined treatment of steam explosion and laccase are better than that of only steam explosion method, and its performances could meet the requirements of textile fibers [65]. Liu et al. used Ganoderma lucidum white-rot fungi to grow cotton stalk, and prepared a new type of sustainable mycelium/cotton stalk composite materials by hot-pressed at $200{ }^{\circ} \mathrm{C}$. The flexural strength and internal bonding strength of obtained composite materials were close to non-load-bearing fiberboard [66]. In addition to traditional applications, cotton stalks can be used as raw materials for new energy sources, such as biomass briquettes [67], gasification [68], and biofuel production [69]. Cotton stalks can also be used to prepare activated carbon with excellent properties [70].

In most applications, pretreatment is required to improve the permeability of the chemical liquid to cotton stalk. However, like other high plants, most of the outer surface of cotton stalk bark (CSB) tissue is covered by plant cuticle. The function of the plant cuticle is to restrict the transport of water and solutes across the apoplast, and to protect plants from chemical and mechanical damage, pests, and pathogens [71]. Therefore, the presence of the plant cuticle makes it difficult for liquid to access from the outer surface of CSB, which reduces the penetration efficiency of chemical liquid to the CSB. In addition, plant cells have dense and complex cell walls, and cell walls hinder the entry of chemical liquid into the fiber. In recent years, many researchers have used different methods to pretreat biomass, and different pretreatment methods have their own advantages and disadvantages [72-83]. To obtain CSB fibers, Reddy and Yang used sodium hydroxide to remove non-fibrous materials [84]. Although chemical methods are efficient, they pollute the environment and their severe reaction conditions affect the fibers adversely. Therefore, environmental and gentle treatment methods are urgently needed to increase the permeability of CSB.

In recent years, to reduce environmental pollution, biotechnology has been widely used in various industries. Biological enzymes have become important products of biotechnology due to their mild reaction, high catalytic reaction efficiency, and strong specificity. Among them, cellulase is a kind of complex catalytic enzyme, including endoglucanase, exoglucanase, and $\beta$-glucosidase, which hydrolyzes cellulose into glucose units [85]. Jin et al. discussed the promotion of water-soluble lignin on cellulase hydrolysis [86]. In recent studies, cellulase has been used in the deinking process of mixed wastepaper of old newspapers and old magazine pulp to increase the deinking efficiency under mild conditions [87]. Jiang et al. used lipase to treat wheatgrass and explored the relationship between biological enzymes and their characteristic information [88]. There are many reports on the pretreatment of cotton stalk powder using chemical or biological methods [89-91]. Researchers have never stopped studying the surface of biomass [92-94]. For example, Teng et al. used bacterial liquid to pretreat cotton stalks to enhance the performance of paper products [95]. Xie et al. reported the surface structure and morphology of cotton stalk with 1-butyl-3-methylimidazole chloride treatment [96]. Nevertheless, in recent years, there has been limited information on the surface properties of CSB treated with cellulase.

Therefore, in this work, the hydrolysis products and surface of CSB were explored by cellulase treatment. The changes in microscopic morphologies and surface compositions, the degradation of CSB lignin, and the dissolution of monosaccharides were investigated. These results of the experiment can be used as a reference basis for increasing the permeability of natural fibers and the subsequent treatment effects of biomass products.

\section{Materials and methods}

\subsection{Treatment of cotton stalk with cellulase}

The cotton stalks used in this study were obtained from Dezhou, Shandong Province, China. The cotton stalks were cut into 40-60-mm-long sections, washed, and dried in the sun to a constant moisture content $(\%, 6.2 \pm 0.5)$. Peel the cotton stalk skin off and cut it into small pieces. The enzyme activity of the liquid neutral cellulase obtained from Shandong Longkete Enzyme Preparation Co., Ltd. (Shandong Province, China) was $800 \mathrm{U} / \mathrm{mL}$. Cellulase was diluted with citric acid-sodium citrate buffer solution ( $\mathrm{pH}$ 6.0), and the cellulase activity after dilution was $100 \mathrm{U} / \mathrm{mL}$. The experiment was carried out on $2.0 \mathrm{~g}$ (dry weight) of CSB in a $100-\mathrm{mL}$ conical flask containing citric acid-sodium citrate buffer solution ( $\mathrm{pH} \mathrm{6.0),} \mathrm{and} \mathrm{the} \mathrm{solid-liquid} \mathrm{ratio} \mathrm{was} \mathrm{1:6.}$ The cellulase dosages were $10 \mathrm{U} / \mathrm{g}, 25 \mathrm{U} / \mathrm{g}, 50 \mathrm{U} / \mathrm{g}, 75 \mathrm{U} / \mathrm{g}$, and $100 \mathrm{U} / \mathrm{g}$, respectively. Then, these conical flasks were placed on a shaker at $60{ }^{\circ} \mathrm{C}$ and incubated with shaking at a speed of $80 \mathrm{rpm}$ for $90 \mathrm{~min}$. The control experiments were carried out in the same solid-liquid ratio conditions without adding cellulase. These systems were placed in the water bath at $95^{\circ} \mathrm{C}$ for $5 \mathrm{~min}$ to terminate the enzyme reaction, filtered them, and the filtrates were sealed at $4{ }^{\circ} \mathrm{C}$. The treated CSB block was freeze-dried for $24 \mathrm{~h}$ and kept sealed 
in a polyethylene bag, and subsequent measurements were carried out at room temperature.

\subsection{Determination of the sugar component and lignin content of the treatment solution}

The treatment effects of different cellulase dosages were determined by measuring lignin and sugars, which were derived from lignin, cellulose, and hemicellulose dissolved in the treatment liquid. One milliliter of treatment solution was mixed with $70 \mu \mathrm{L}$ of $72 \% \mathrm{H}_{2} \mathrm{SO}_{4}$ and $0.93 \mathrm{~mL}$ of deionized water $\left(3.33 \% \mathrm{H}_{2} \mathrm{SO}_{4}\right)$ in a digester (GL-16, Shandong Greencare Precision Instrument Co., Ltd., China) for $60 \mathrm{~min}$ acid hydrolysis at $121{ }^{\circ} \mathrm{C}$ [97]. The monosaccharide concentrations were determined by ion chromatography with CarboPactrade PA20 $(3 \mathrm{~mm} \times 150 \mathrm{~mm})$ analytical column, guard column $(3 \times 30 \mathrm{~mm})$, autosampler, and EC detector with Au working electrode and $\mathrm{Ag} / \mathrm{AgCl}$ reference electrode (Dionex ICS5000 +, Thermo Fisher Scientific, America). The mobile phase was $250 \mathrm{mM} \mathrm{NaOH}$ and deionized water at a flow rate of $0.4 \mathrm{~mL} / \mathrm{min}$. Monosaccharides (L-arabinose, D-galactose, D-glucose, $\underline{D}$-xylose, and D-mannose) at concentrations of $0.5,1,2,5$, and $10 \mathrm{mg} / \mathrm{L}$ were used as standards. Before the ion chromatography injection, the standard and samples should be filtered through a $0.22-\mu \mathrm{m}$ Millipore membrane filter [98].

The enzyme treatment solution was precipitated by a dilute hydrochloric acid solution ( $\mathrm{pH}$ 2.0) [99], and there was no obvious acid-insoluble lignin. The amount of lignin that appeared in the text was represented by acid-soluble lignin. According to the method of GBT10337-2008, the absorbance value of the treatment solution was measured by an ultraviolet-visible spectrophotometer (Agilent 8453, Agilent Technologies Inc., America) at wavelength of $205 \mathrm{~nm}$, and the background run with $3 \% \mathrm{H}_{2} \mathrm{SO}_{4}$. Dilute the sample as needed to achieve absorbance of $0.7-1.0$ and record the dilution. The lignin content is calculated as follows:

$\rho=A D 1000 / 110$

where $\rho$ is the lignin content $(\mathrm{mg} / \mathrm{L}) ; A$ is the absorbance; $D$ is the dilution multiple of treatment solution; 110 is the absorbance coefficient $\left(\mathrm{L} \cdot \mathrm{g}^{-1} \cdot \mathrm{cm}^{-1}\right)$.

\subsection{Microscopic image, EDX spectra, and XPS analysis}

A scanning electron microscope (SEM) and nano-CT were used to observe the morphology and microstructure of cellulase-treated and untreated CSB surfaces. SEM images of the sample were scanned with an EM 30 plus + scanning electron microscope (COXEM Company, South Korea) at an accelerating voltage of $20 \mathrm{kV}$. The EDX spectra were obtained using a Model 550i EDS Detector Power coupled to a TM4000Plus scanning electron microscope.

The CSB sample was made into a rod shape $(2 \mathrm{~mm} \times 8 \mathrm{~mm})$, and the Skayscan 2211 X-ray CT (Bruker Company, Germany) was used to scan the sample with a resolution of $300 \mathrm{~nm}$ and a scanning angle of $180^{\circ}$. The obtained micro-CT images were processed by CTvox software.

The X-ray photoelectron spectroscopy (XPS) spectra of the CSB outer skin before and after treatment were obtained by XPS microprobe instrument (PHI-5000 VersaProbe, Ulvac-Phi, Japan, monochromated Al K $\alpha$ source, $h v=1486.6 \mathrm{eV})$.

\section{Results and discussion}

\subsection{Analysis of monosaccharides and lignin}

The amount of monosaccharide and lignin dissolved in the CSB treatment solution is shown in Fig. 1. The dissolved amounts of arabinose, galactose, xylose, and mannose of CSB treated with different amounts of cellulase are shown in Fig. 1a. The solubility of the four monosaccharides all increased with increase of cellulase, and the dissolution amount of mannose increased significantly. Besides, the dissolution of glucose and lignin in Fig. 1b showed an upward trend. Like the four monosaccharides in Fig. 1a, the dissolution of glucose and lignin is higher, and their contents are both beyond $2.8 \mathrm{~g} / \mathrm{L}$ when the cellulase dosage is $100 \mathrm{U} / \mathrm{g}$. It is because that cellulase can play an important role in the hydrolysis of cellulose. Cellulase is composed of three enzymes: endoglucanase, cellobiohydrolase, and $\beta$-glucosidase. Both endoglucanase and cellobiohydrolase can react with cellulose directly, and cellobiohydrolase can cut the cellulose chain to reduce the length of the cellulose chain [100].

Cellulose is made up of D-glucopyranosyl groups connected by $1,4-\beta$-glycosidic bonds, and hydrogen bonds connect the polysaccharide chains to form cellulose microfibers. Cellulose microfibers are connected to hemicellulose containing complex polysaccharides [101]. While the main sugar groups of hemicellulose are D-xylose, D-mannosyl, D-glucosyl, D-galactosyl, L-arabinosyl, 4-O-methyl-D-glucuronic acid group, D-galacturonic acid group, and D-glucuronic acid group, two or more of these glycan groups constitute different glycans [102]. Lignin is intertwined with polysaccharide structure in the cell wall [103]. While the cellulase hydrolyzes the cellulose, it is accompanied by the exfoliation of some hemicellulose glycans and lignin. Based on the above mentioned, one can conclude that with the increase of cellulase, the dissolution of the four monosaccharides and lignin in the 

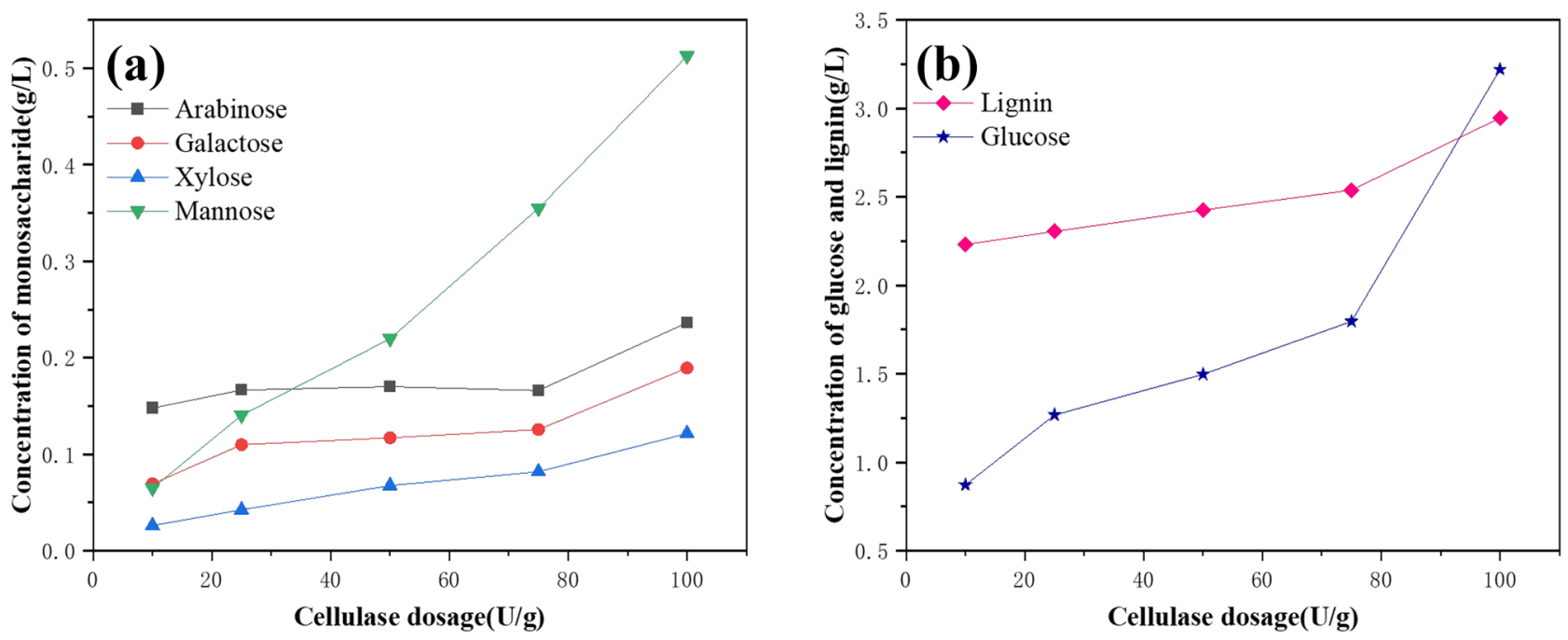

Fig. 1 The influence of different cellulase dosages on the dissolution of a arabinose, galactose, xylose, mannose, $\mathbf{b}$ glucose, and lignin in CSB cellulase treatment solution

CSB cellulase treatment solution rises, which is consistent with the above analysis.

\subsection{Micro-CT image analysis}

The micro-CT images of CSB treated with different cellulase enzymes are shown in Fig. 2. As shown in Fig. 2a and c, compared with the blank group (Fig. 2a), it can be observed that the wall of the CSB catheter changed from compact to lose after cellulase treatment. When the amount of enzyme was increased to $100 \mathrm{U} / \mathrm{g}$, the degree of looseness reached the highest. In addition, the phloem fiber cell wall of CSB without cellulase treatment was thicker, the cell cavity was smaller, and the cell arrangement was more compact as shown in Fig. 2(a2). As for Fig. 2(b2), the cell wall of phloem fiber of CSB treated with cellulase became thinner, the cell cavity became larger, and the cell arrangement was looser. While further increased the cellulase dosage, the cell wall of phloem fiber did not change notably (Fig. 2(c2)).
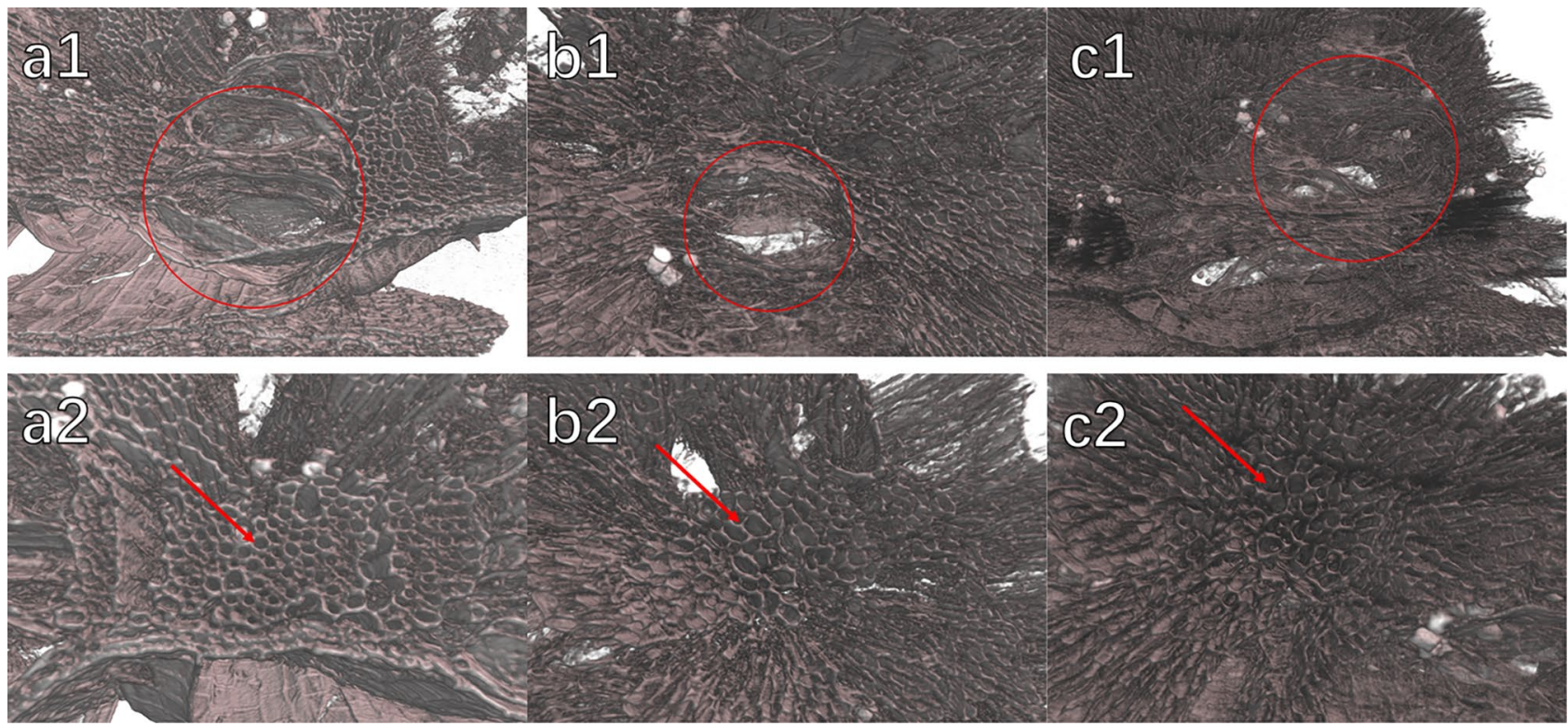

Fig. 2 CSB micro-CT images: $0 \mathrm{U} / \mathrm{g}$ cellulase treatment of CSB a1 duct, and $\mathbf{a} 2$ fiber cell wall; $50 \mathrm{U} / \mathrm{g}$ cellulase treatment of CSB b1 duct, and b2 fiber cell wall; and $100 \mathrm{U} / \mathrm{g}$ cellulase treatment of CSB c1 duct, and $\mathbf{c 2}$ fiber cell wall 
The reason for this phenomenon is that the cell wall of plant is mainly composed of two parts: primary wall and secondary wall, and there is an intercellular layer between adjacent cells. Cellulose and hemicellulose are the main components of the primary wall. Lignin acts as an adhesive and support between cells and mainly exists in the intercellular layer [104]. Cellulose, hemicellulose, and lignin peeled off simultaneously, when cellulase acted on the phloem cell wall of CSB. Then, these processes resulted in the thinning of the phloem fiber cell wall of CSB (Fig. 2(b2)). Lignocellulose plant cell walls are composed of crystalline cellulose nanofibers embedded in an amorphous matrix of crosslinked lignin and hemicellulose. This characteristic structure reduces the accessibility of enzymes and microorganisms [105]. Therefore, increase the amount of enzyme within a certain range, and cellulase cannot enzymatically hydrolyze cellulose with high crystallinity. This could explain why there were no significant changes in the cell walls of phloem fibers (Fig. 2(c2)). While the large duct lumen existing between the fiber cells facilitated the penetration and action of cellulase, and the effect of cellulase was also stronger, the phenomenon was consistent with the above dissolution tendency of monosaccharides and lignin in Fig. 1.

\subsection{SEM image analysis}

SEM images of the outer skin surface and bast fiber surface of CSB treated with different amounts of cellulase are shown in Figs. 3 and 4. It can be seen from Fig. 3a that the outer skin surface of the untreated CSB showed an undamaged intact state with thick stratum corneum and honeycomb profile. Under buffer treatment, the complete stratum corneum with a large outer skin thickness showed no cracks and pores, and was similar to untreated CSB, as shown in Fig. 3b. These results indicated that the buffer treatment used in the blank group had little effect on the morphology of the outer skin of CSB.

The SEM image in Fig. 3c showed slight cracks in the stratum corneum of CSB under low cellulase dosage, and shedding substances began to appear on the surface. However, no obvious pores and support structures of honeycomb exposed. When the dosage of cellulase increased to $50 \mathrm{U} / \mathrm{g}$, the outer skin of CSB began to collapse and obvious pores appeared (Fig. 3d). But the degree of exfoliation was low, and no intradermal structure was seen. After $75 \mathrm{U} / \mathrm{g}$ cellulase treatment (Fig. 3e), the outer skin of CSB appeared large degree of shedding, and the internal structure emerged. Furthermore, as shown in Fig. 3f, it can be observed that the stratum corneum of the outer epidermis of CSB was completely exfoliated in large areas, and the honeycomb structure was clearly visible behind the epidermis with the dosage of $100 \mathrm{U} / \mathrm{g}$ cellulase. These results indicated that cellulase destroyed the stable and dense stratum corneum structure on the outer surface of CSB [106]. The destruction of dense structures, the breaking of stable connections, and the detachment of surface fragments might increase the external surface area of CSB, which could improve the accessibility of cellulose [107].

The morphology characteristics of inner surface of the untreated and treated CSB are shown in Fig. 4. Consistent with the outer surface of CBS, the inner surface of untreated (Fig. 4a) and buffer-treated (Fig. 4b) CBS showed similar
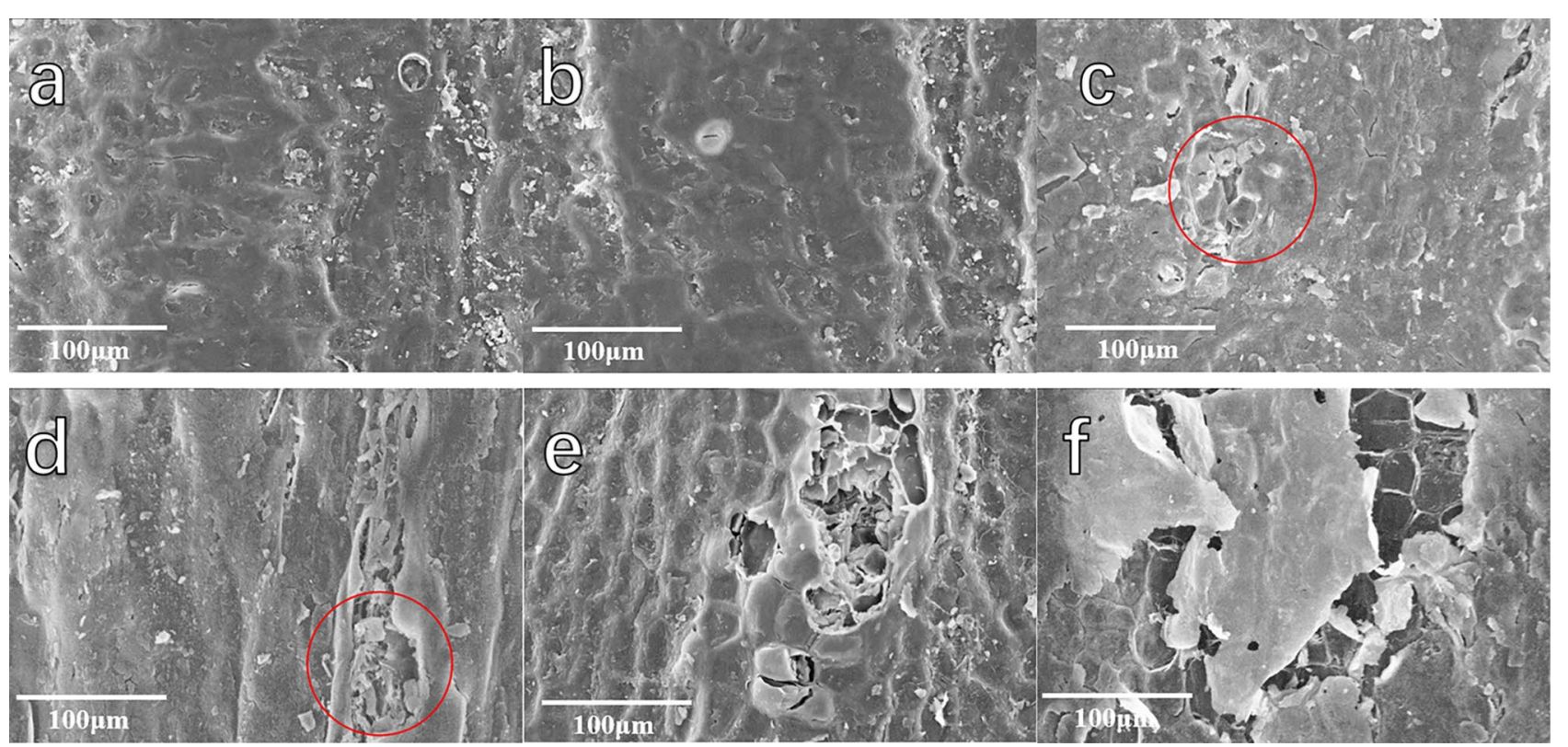

Fig. 3 CSB (outer skin surface) SEM images of a untreated CSB; cellulase-treated CSB: b 0 U/g, c 25 U/g, d 50 U/g, e 75 U/g, and f 100 U/g 

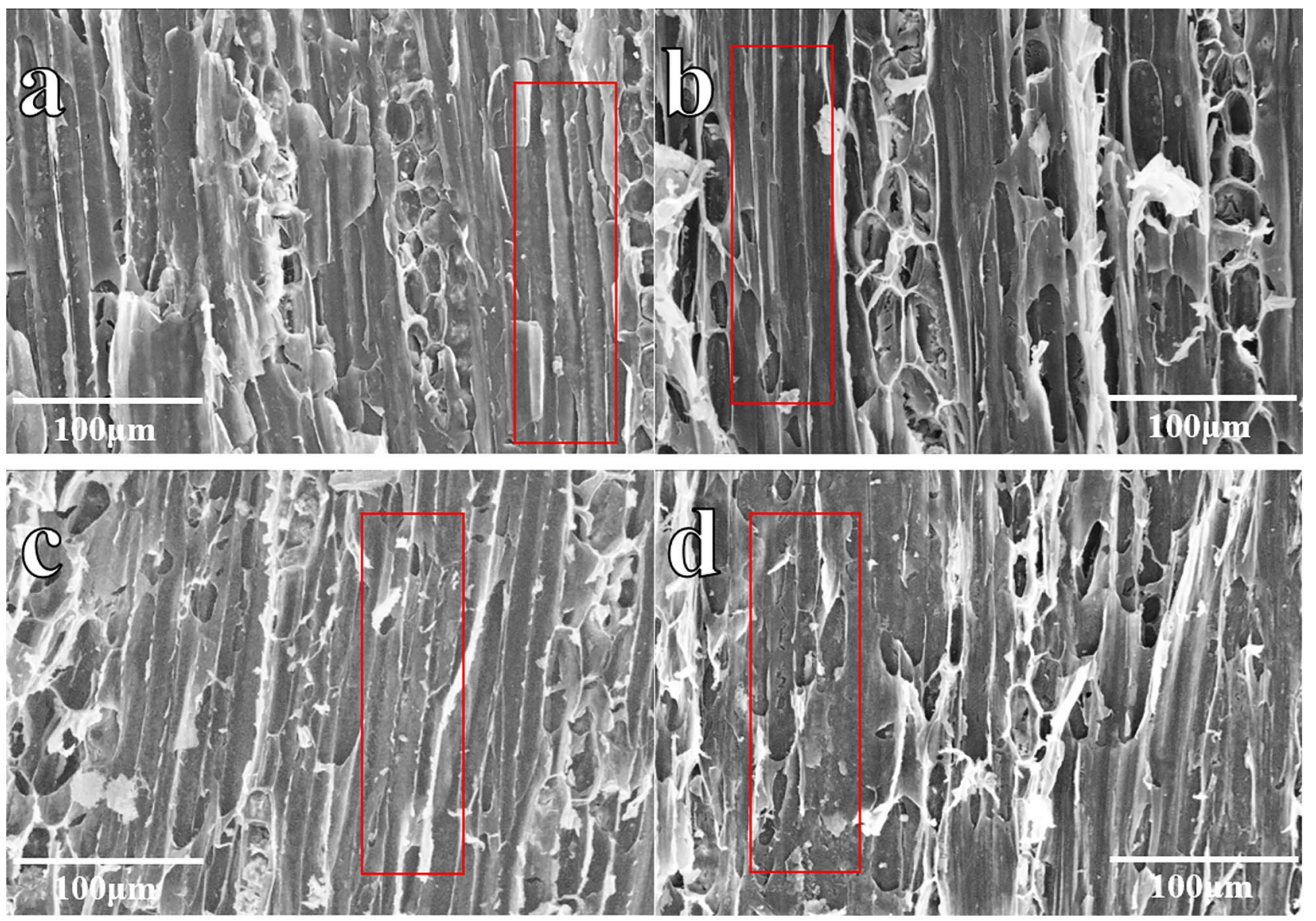

Fig. 4 CSB (bast fiber surface) SEM images of a untreated CSB; cellulase-treated CSB: b 0 U/g, c 50 U/g, and d 100 U/g

morphologies. Both of them presented sharp, complete, and well-defined raised boundaries in the phloem fiber cells. And the surface of the phloem fibers was smooth and compact. Compared with Fig. 4b, it can be noticed that partial edges of original sharp phloem fibers were shed after $50 \mathrm{U} / \mathrm{g}$ cellulase treatment (Fig. 4c). When the dosage of enzyme was increased to $100 \mathrm{U} / \mathrm{g}$, the bumps on the edge of the bast fiber almost disappeared, and the boundary of the phloem fibers became relatively flat. Meanwhile, the bast fiber also began to fall off and the surface became rough. These phenomena indicated that cellulase destroyed the compact structure of bast fibers. The damage of the bast fibers was aggravated

Table 1 CSB outer surface elemental compositions

\begin{tabular}{lll}
\hline Cellulase dosage (U/g) & Element & $\begin{array}{l}\text { Concentration } \\
\text { (wt\%) }\end{array}$ \\
\hline 0 & $\mathrm{O}$ & 52.436 \\
& $\mathrm{Si}$ & 47.564 \\
100 & $\mathrm{O}$ & 93.433 \\
& $\mathrm{Si}$ & 6.567
\end{tabular}

with the increase of cellulase dosage. These changes represented greater accessibility of cellulose [65], which was consistent with the analysis results of the micro-CT images.

\subsection{SEM-EDX spectra analysis}

The main elemental compositions on the outer and inner surface of untreated and treated CSB examined using SEM-EDX spectra are summarized in Tables 1 and 2. As seen from Tables 1 and 2, the elemental compositions of the outer surface of the cellulase-treated CSB were different from those of the inner surface. After $100 \mathrm{U} / \mathrm{g}$ cellulase

Table 2 CSB inner surface elemental compositions

\begin{tabular}{llc}
\hline Cellulase dosage (U/g) & Element & $\begin{array}{l}\text { Concentration } \\
(\mathrm{wt} \%)\end{array}$ \\
\hline 0 & $\mathrm{O}$ & 93.248 \\
& $\mathrm{Si}$ & 6.752 \\
100 & $\mathrm{O}$ & 97.880 \\
& $\mathrm{Si}$ & 2.120 \\
\hline
\end{tabular}



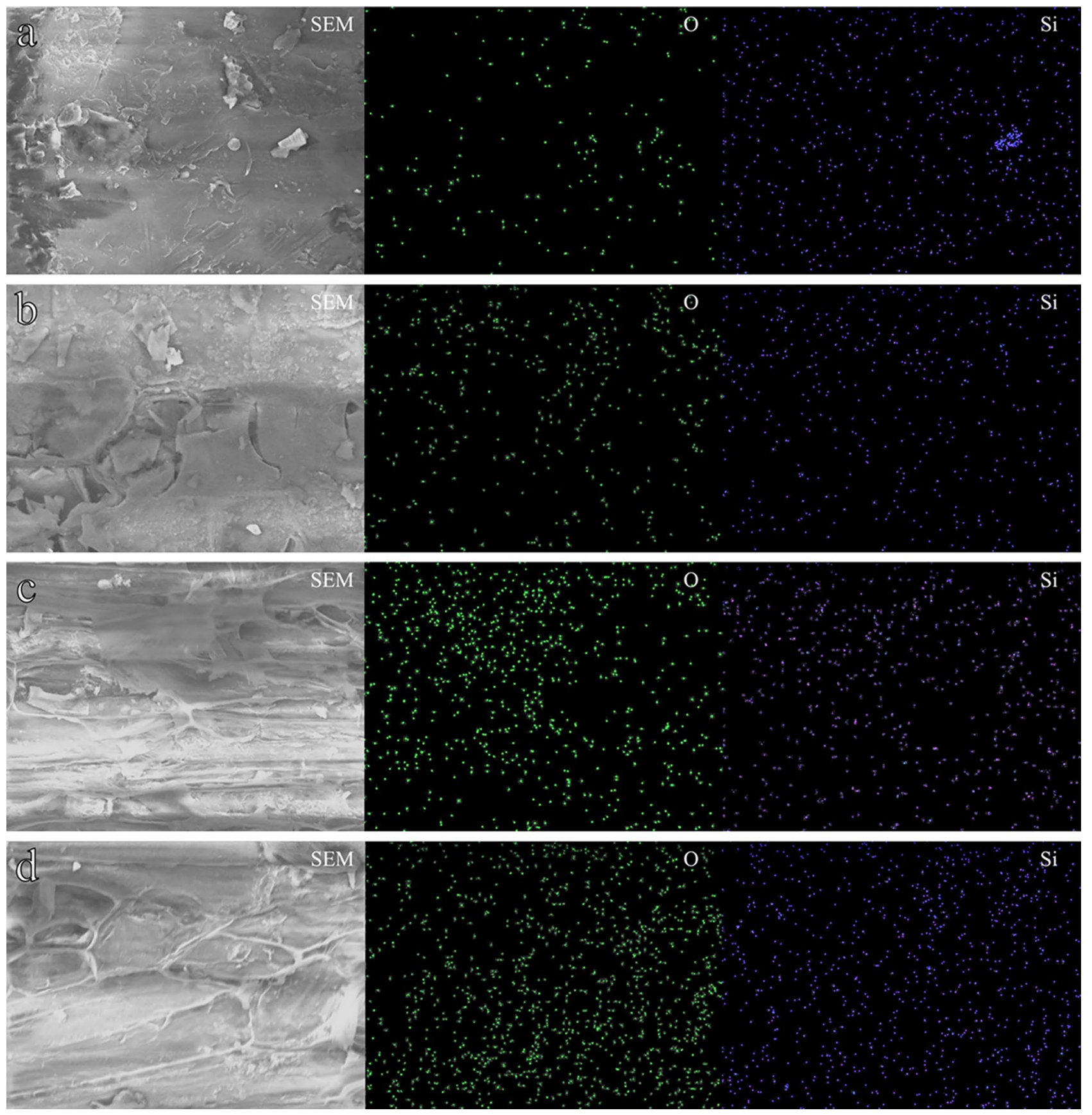

Fig. 5 The EDS element mappings of CSB outer surface with a $0 \mathrm{U} / \mathrm{g}$ and b $100 \mathrm{U} / \mathrm{g}$, and inner surface with c $0 \mathrm{U} / \mathrm{g}$ and d $100 \mathrm{U} / \mathrm{g}$

treatment, the $\mathrm{Si}$ element concentration on the outer surface of CSB decreased from 47.567 to $6.567 \mathrm{wt} \%$. But the Si element concentration on the inner surface of the CSB was much lower. The Si element concentration on the inner surface of CSB without cellulase treatment was $6.752 \mathrm{wt} \%$, which was similar to that of the cellulase-treated outer surface. Plants uptake $\mathrm{Si}$ from the soil solution as $\mathrm{H}_{4} \mathrm{SiO}_{4}$. The polymerization of converting $\mathrm{H}_{4} \mathrm{SiO}_{4}$ into insoluble silica generally occurs in the cuticle and plant cell walls, and $\mathrm{Si}$ is further deposited beneath the cuticle [108]. Because of the presence of $\mathrm{Si}$ in the stratum corneum, the concentration of $\mathrm{Si}$ on the outer surface of CSB without cellulase treatment is relatively high. After cellulase treatment, the cuticle was destroyed and the Si concentration on the outer surface of CSB decreased significantly. After the cuticle was destroyed, the $\mathrm{Si}$ concentration on the outer surface is closer to that inner surface. In addition, the phloem fiber cell wall on the inner surface of CSB was damaged by cellulase, and the $\mathrm{Si}$ 

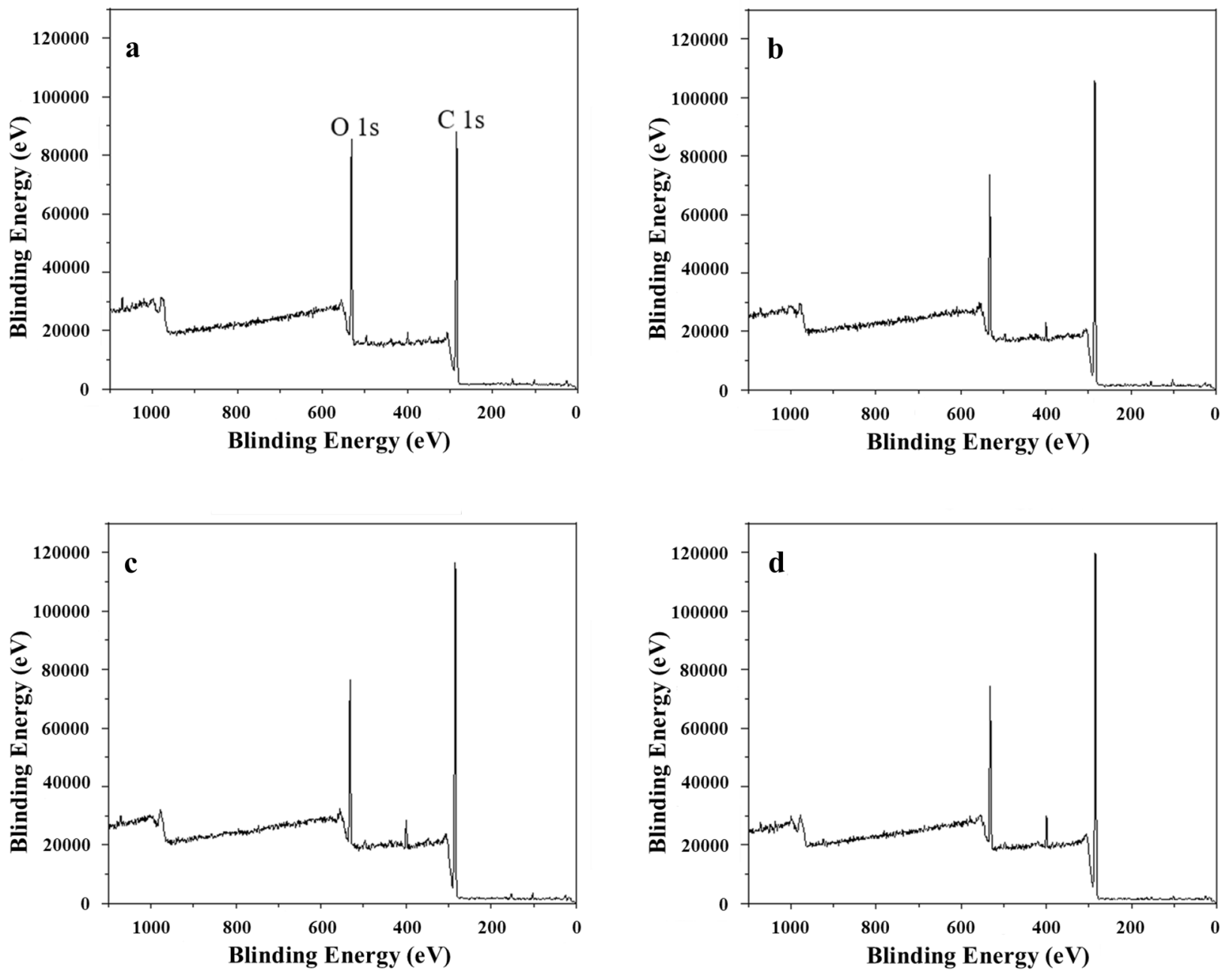

Fig. 6 XPS survey spectra of cellulase-treated CSB: a $0 \mathrm{U} / \mathrm{g}$, b $25 \mathrm{U} / \mathrm{g}$, c $50 \mathrm{U} / \mathrm{g}$, and d $100 \mathrm{U} / \mathrm{g}$

element concentration decreased slightly. These results are consistent with the results of SEM images and EDS element mappings in Figs. 3, 4, and 5.

\subsection{XPS analysis}

\subsection{1 $\mathrm{O} / \mathrm{C}$ ratio}

The chemical environment and atomic concentration of CSB samples can be obtained by XPS analysis. Figure 6 shows XPS spectra of the outer skin of CSB treated with different amounts of cellulase. The XPS spectra data was analyzed and calculated by Thermo Avantage software to obtain the experimental atomic composition of CSB, and the rates of oxygen-carbon (O/C) are calculated in Table 3. Compared with the control group, the $\mathrm{O} / \mathrm{C}$ on the outer surface of CSB treated with cellulase decreased significantly. With the amount of enzyme increased, O/C continued to decrease, but decreased slightly. Cellulase treatment caused enzymatic hydrolysis of the cellulose on the outer surface, resulting in a decrease in the content of carbohydrate and an increase of lignin and extracts on the outer surface of CSB [109]. The high amount of cellulase did not continue to change the content of cellulose, hemicellulose, and lignin in the outer epidermis of CSB prominently, which may be related to the degree of exfoliation of the outer epidermis and the accessibility of cellulase.

Table 3 Experimental atomic composition (\%) and $\mathrm{O} / \mathrm{C}$ ratio obtained by XPS analysis for CSB outer surface

\begin{tabular}{llllll}
\hline $\begin{array}{l}\text { Cellulase dosage } \\
(\mathrm{U} / \mathrm{g})\end{array}$ & $\% \mathrm{C}$ & $\% \mathrm{O}$ & $\% \mathrm{~N}$ & $\% \mathrm{Si}$ & $\mathrm{O} / \mathrm{C}$ \\
\hline 0 & 72.8 & 21.7 & 3.7 & 1.8 & 0.30 \\
25 & 78.2 & 16.4 & 3.2 & 2.2 & 0.21 \\
50 & 77.3 & 14.8 & 5.8 & 2.2 & 0.19 \\
100 & 79.1 & 14.5 & 5.2 & 1.2 & 0.18 \\
\hline
\end{tabular}


Fig. $7 \mathrm{C} 1 \mathrm{~s}$ peaks of cellulasetreated CSB: a $0 \mathrm{U} / \mathrm{g}$, b $25 \mathrm{U} / \mathrm{g}$, c $50 \mathrm{U} / \mathrm{g}$, and d $100 \mathrm{U} / \mathrm{g}$
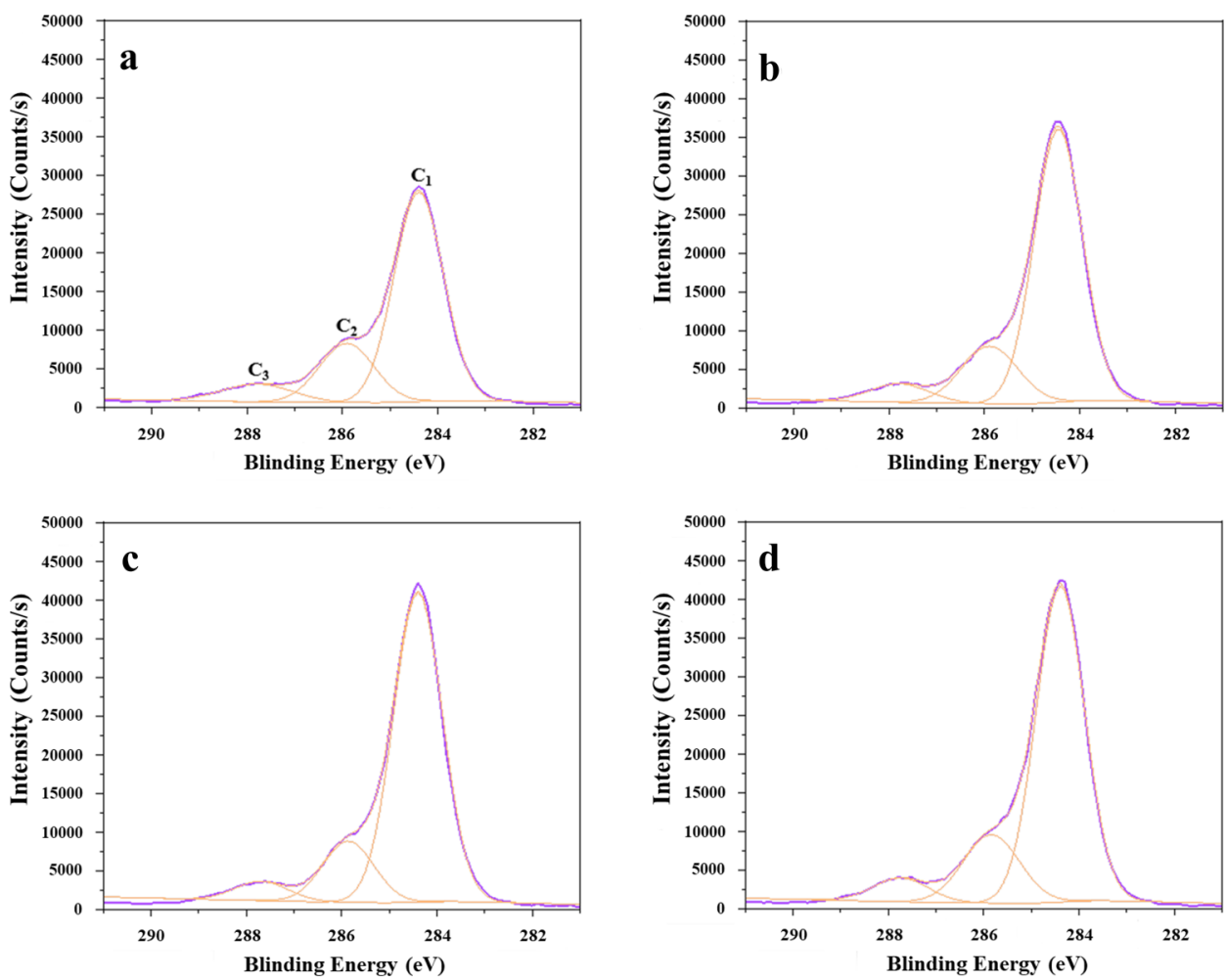

\subsubsection{C1s peak}

The C1s high-resolution spectra of CSB treated with different cellulase dosages are shown in Fig. 7. The XPS spectrum of $\mathrm{C} 1 \mathrm{~s}$ can be deconvoluted into three peaks. The $\mathrm{C} 1$ peak corresponds to aliphatic and aromatic carbon bonds, which are derived from carbon, extract, and lignin. And the $\mathrm{C} 2$ peak corresponds to carbon-oxygen bonds and is derived from all wood compounds, especially cellulose and hemicellulose. While the $\mathrm{C} 3$ peak represents the bonding of two oxygen atoms or the carbon atoms in the ketone group, which are mainly from cellulose and hemicellulose [110], the $\mathrm{C} 1$ peak in all samples was much stronger than the $\mathrm{C} 2$ and $\mathrm{C} 3$ peaks. The $\mathrm{C} 1$ peak became stronger as the amount of cellulase increased. It indicated that cellulose and hemicellulose were hydrolyzed by cellulase, and the concentration of polysaccharides on the outer surface of CSB decreased [111]. Based on the above results, it is speculated that the cellulase used in the article was not enough to destroy the deep-layer fibers of CSB. Then, only the fibers on the surface of CSB can be enzymatically hydrolyzed [112]. Therefore, when the cellulase dosage is increased to a certain amount, the ratio of polysaccharide and lignin on the surface of CSB tends to stabilize.

\section{Conclusions}

In this study, cellulase had a destructive effect on the cuticle and fiber cell wall of CSB. Cellulase hydrolyzed the polysaccharides of CSB, which led to the decomposition of polysaccharides and the dissolution of lignin. The results of ion chromatography showed that as the amount of cellulase increased, the amount of arabinose, galactose, xylose, mannose, glucose, and lignin in the CSB treatment solution increased. While cellulase hydrolyzed cellulose, it was accompanied by the shedding of some hemicellulosans and lignin. At the same time, cellulase destroyed the stratum corneum of CSB, exposed more polysaccharides and lignin, and increased the accessibility of cellulase. Compared with the control group, the cell wall of CBS bast fibers treated with cellulase was significantly thinner.

Therefore, using cellulase for the pretreatment of CSB, the dense protective structure of CSB was destroyed. It is expected that the accessibility of subsequent processing liquids to the internal structure of CSB will be increased. This research provides a new method and basis for improving the liquid permeability of CSB. However, it is necessary to further study the mechanism of cellulase destroying the stratum corneum on the outer surface of CSB. 
Acknowledgements The authors would like to express thanks for the supports from National Key R\&D Program of China, Grant No. 2019YFC1905900; National Natural Science Foundation of China, Grant No.31870566; Taishan Scholars Program and Yuandu Leading Talents Program, and Foundation of State Key Laboratory of Biobased Material and Green Papermaking, Qilu University of Technology, Shandong Academy of Sciences (No. GZKF202001).

\section{Declarations}

Conflict of interest The authors declare no competing interests.

Open Access This article is licensed under a Creative Commons Attribution 4.0 International License, which permits use, sharing, adaptation, distribution and reproduction in any medium or format, as long as you give appropriate credit to the original author(s) and the source, provide a link to the Creative Commons licence, and indicate if changes were made. The images or other third party material in this article are included in the article's Creative Commons licence, unless indicated otherwise in a credit line to the material. If material is not included in the article's Creative Commons licence and your intended use is not permitted by statutory regulation or exceeds the permitted use, you will need to obtain permission directly from the copyright holder. To view a copy of this licence, visit http://creativecommons.org/licenses/by/4.0/.

\section{References}

1. Shaikh A, Gurjar R, Patil P, Paralikar K, Varadarajan P, Balasubramanya R (2010) Particle boards from cotton stalk. Central Institute for Research on Cotton Technology, Mumbai, India

2. Liu H, Du H, Zheng T, Liu K, Ji X, Xu T, Zhang X, Si C (2021) Cellulose based composite foams and aerogels for advanced energy storage devices. Chem Eng J 426:130817. https://doi. org/10.1016/j.cej.2021.130817

3. Liu K, Du H, Zheng T, Liu W, Zhang M, Liu H, Zhang X, Si C (2021) Lignin-containing cellulose nanomaterials: preparation and applications. Green Chem. https://doi.org/10.1039/D1GC02841C

4. Hossain MT, Hossain MS, Uddin MB, Khan RA, Chowdhury AMS (2020) Preparation and characterization of sodium silicate-treated jute-cotton blended polymer-reinforced UPR-based composite: effect of $\gamma$-radiation. Adv Compos Hybrid Mater 4:257-264. https://doi.org/10.1007/s42114-020-00162-4

5. Tyagi P, Chaturvedi R, Gorhe NR, Gîjiu CL (2021) Electroresponsive epoxy-polypyrrole-cotton composites with enhanced flexural strength and water resistance. Mater Res Bull 137. https:// doi.org/10.1016/j.materresbull.2020.111197

6. Wu Y, Luo Z, Wang X, Fu G, Lei W, Zou Y, Yin B, Ma Z, Pan Y, Jiang W (2022) Cotton-like CNTs/(Ni-P)/S composites with enhanced electrochemical performance of lithium-sulfur battery. Mater Res Bull 145. https://doi.org/10.1016/j.materresbull.2021. 111529

7. Sun J, Shi L, Song T, Sun C (2021) Flame resistance of cotton fabric finishing with $\mathrm{N}$-hydroxymethylacrylamide spirophosphate. Adv Compos Hybrid Mater. https://doi.org/10.1007/ s42114-021-00348-4

8. Kaur U, Oberoi HS, Bhargav VK, Sharma-Shivappa R, Dhaliwal SS (2012) Ethanol production from alkali- and ozone-treated cotton stalks using thermotolerant Pichia kudriavzevii HOP-1. Ind Crop Prod 37:219-226. https://doi.org/10.1016/j.indcrop.2011. 12.007

9. Singh A, Bajar S, Bishnoi NR (2017) Physico-chemical pretreatment and enzymatic hydrolysis of cotton stalk for ethanol production by Saccharomyces cerevisiae. Bioresour Technol 244:71-77. https://doi.org/10.1016/j.biortech.2017.07.123

10. An L, Si C, Wang G, Sui W, Tao Z (2019) Enhancing the solubility and antioxidant activity of high-molecular-weight lignin by moderate depolymerization via in situ ethanol/acid catalysis. Ind Crop Prod 128:177-185. https://doi.org/10.1016/j.indcrop. 2018.11.009

11. Xu R, Du H, Liu C, Liu H, Wu M, Zhang X, Si C, Li B (2021) An efficient and magnetic adsorbent prepared in a dry process with enzymatic hydrolysis residues for wastewater treatment. J Clean Prod 313:127834. https://doi.org/10.1016/j.jclepro.2021. 127834

12. Chen S, Wang G, Sui W, Parvezc AM, Dai L, Si C (2020) Novel lignin-based phenolic nanosphere supported palladium nanoparticles with highly efficient catalytic performance and good reusability. Ind Crop Prod 145:112164. https://doi.org/ 10.1016/j.indcrop.2020.112164

13. Xu J, Li C, Dai L, Xu C, Zhong Y, Yu F, Si C (2020) Biomass fractionation and lignin fractionation towards lignin valorization. Chemsuschem 13(17):4284-4295. https://doi.org/10. $1002 /$ cssc. 202001491

14. Liu H, Xu T, Liu K, Zhang M, Liu W, Li H, Du H, Si C (2021) Lignin-based electrodes for energy storage application. Ind Crop Prod 165:113425. https://doi.org/10.1016/j.indcrop.2021. 113425

15. Hu W, Wang X, Wu L, Shen T, Ji L, Zhao X, Si C, Jiang Y, Wang G (2016) Pigenin-7-O-beta-D-glucuronide inhibits LPSinduced inflammation through the inactivation of AP-1 and MAPK signaling pathways in RAW 264.7 macrophages and protects mice against endotoxin shock. Food Func 7(2):10021013. https://doi.org/10.1039/c5fo01212k

16. Dai L, Li Y, Kong F, Liu K, Si C, Ni Y (2019) Lignin-based nanoparticles stabilized pickering emulsion for stability improvement and thermal-controlled release of transresveratrol. ACS Sustain Chem Eng 7(15):13497-13504. https://doi. org/10.1021/acssuschemeng.9b02966

17. Liu K, Du H, Liu W, Liu H, Zhang M, Xu T, Si C (2022) Cellulose nanomaterials for oil exploration applications. Polym Rev. https://doi.org/10.1080/15583724.2021.2007121

18. Pei W, Shang W, Liang C, Jiang X, Huang C, Yonga Q (2020) Using lignin as the precursor to synthesize Fe3O4@lignin composite for preparing electromagnetic wave absorbing lignin-phenolformaldehyde adhesive. Ind Crop Prod 154:112638. https://doi.org/ 10.1016/j.indcrop.2020.112638

19. Huang C, Jiang X, Shen X, Hu J, Tang W, Wu X, Ragauskas A, Jameel H, Meng X, Yong Q (2021) Lignin-enzyme interaction: a roadblock for efficient enzymatic hydrolysis of lignocellulosics. Renew Sust Energ Rev 154:111822. https://doi.org/10.1016/j. rser.2021.111822

20. Wang R, Zheng L, Xu Q, Xu L, Wang D, Li J, Lu G, Huang C, Wang Y (2021) Unveiling the structural properties of watersoluble lignin from gramineous biomass by autohydrolysis and its functionality as a bioactivator (anti-inflammatory and antioxidative). Int J Biol Macromol 191:1087-1095. https://doi.org/10. 1016/j.ijbiomac.2021.09.124

21. Zheng L, Lu G, Pe W, Yan W, Li Y, Zhang L, Huang C, Jiang Q (2021) Understanding the relationship between the structural properties of lignin and their biological activities. Int J Biol Macromol 190:291-300. https://doi.org/10.1016/j.ijbiomac.2021.08. 168

22. Lin W, Yang J, Zheng Y, Huang C, Yong Q (2021) Understanding the effects of different residual lignin fractions in acid-pretreated bamboo residues on its enzymatic digestibility. Biotechnol Biofuels 14:143. https://doi.org/10.1186/s13068-021-01994-y

23. Xu T, Du H, Liu H, Liu W, Zhang X, Si C, Liu P, Zhang K (2021) Advanced nanocellulose-based composites for flexible functional 
energy storage devices. Adv Mater 33:202101368. https://doi. org/10.1002/adma.202101368

24. Lu J, Han X, Dai L, Li C, Wang J, Zhong Y, Yu F, Si C (2020) Conductive cellulose nanofibrils-reinforced hydrogels with synergetic strength, toughness, self-adhesion, flexibility and adjustable strain responsiveness. Carbohyd Polym 250:117010. https:// doi.org/10.1016/j.carbpol.2020.117010

25. Du H, Parit M, Liu K, Zhang M, Jiang Z, Huang T, Zhang X, Si C (2021) Engineering cellulose nanopaper with water resistant, antibacterial, and improved barrier properties by impregnation of chitosan and the followed halogenation. Carbohyd Polym 270:118372. https://doi.org/10.1016/j.carbpol.2021.118372

26. Lu J, Zhu W, Dai L, Si C, Ni Y (2019) Fabrication of thermoand $\mathrm{pH}$-sensitive cellulose nanofibrils-reinforced hydrogel with biomass nanoparticles. Carbohyd Polym 215:289-295. https:// doi.org/10.1016/j.carbpol.2019.03.100

27. Du H, Liu W, Zhang M, Si C, Zhang X, Li B (2019) Cellulose nanocrystals and cellulose nanofibrils based hydrogels for biomedical applications. Carbohyd Polym 209:130-144. https://doi. org/10.1016/j.carbpol.2019.01.020

28. Liu K, Du H, Zheng T, Liu H, Zhang M, Zhang R, Li H, Xie H, Zhang X, Ma M, Si C (2021) Recent advances in cellulose and its derivatives for oilfield applications. Carbohyd Polym 259:117740. https://doi.org/10.1016/j.carbpol.2021.117740

29. Dai L, Zhu W, Lu J, Kong F, Si C, Ni Y (2019) A lignin-containing cellulose hydrogel for lignin fractionation. Green Chem 21(19):52225230. https://doi.org/10.1039/c9gc01975h

30. Wang X, Tang S, Chai S, Wang P, Qin J, Pei W, Bian H, Jiang Q, Huang C (2021) Preparing printable bacterial cellulose based gelatin gel to promote in vivo bone regeneration. Carbohyd Polym 270:118342. https://doi.org/10.1016/j.carbpol.2021.118342

31. Xiong R, Xu R, Huang C, Smedt S, Braeckmans K (2021) Stimuliresponsive nanobubbles for biomedical applications. Chem Soc Rev 50:5746-5776. https://doi.org/10.1039/c9cs00839j

32. Amode NS, Jeetah P (2020) Paper production from Mauritian hemp fibres. Waste Biomass Valori 12:1781-1802. https://doi. org/10.1007/s12649-020-01125-y

33. Cao S, Ge W, Yang Y, Huang Q, Wang X (2021) High strength, flexible, and conductive graphene/polypropylene fiber paper fabricated via papermaking process. Adv Compos Hybrid Mater. https://doi.org/10.1007/s42114-021-00374-2

34. Isacsson P, Wang X, Fall A, Mengistie D, Calvie E, Granberg H, Gustafsson G, Berggren M, Engquist I (2020) Highly conducting nanographite-filled paper fabricated via standard papermaking techniques. ACS Appl Mater Interfaces 12:48828-48835. https:// doi.org/10.1021/acsami.0c13086

35. Dai L, Lu J, Kong F, Liu K, Wei H, Si C (2019) Reversible photocontrolled release of bovine serum albumin by azobenzene-containing cellulose nanofibrils-based hydrogel. Adv Compos Hybrid Mater 2:462-470. https://doi.org/10.1007/s42114-019-00112-9

36. Zeng Z, Mavrona E, Sacre D, Kummer N, Cao J, Muller L, a E, Hack E, Zolliker P, Nystrom G (2021) Terahertz birefringent biomimetic aerogels based on cellulose nanofibers and conductive nanomaterials. ACS Nano 15:7451-7462. https://doi.org/10. 1021/acsnano.1c00856

37. Liu W, Si C, Du H, Zhang M, Zhang X, Xie H (2019) Advance in preparation of nanocellulose-based hydrogels and their biomedical applications. J Forest Eng 4(5):11-19. https://doi.org/ 10.1007/s42114-019-00112-9

38. Gu H, Gao C, Zhou X, Du A, Naik N, Guo Z (2021) Nanocellulose nanocomposite aerogel towards efficient oil and organic solvent adsorption. Adv Compos Hybrid Mater 4:459-468. https:// doi.org/10.1007/s42114-021-00289-y

39. Liu W, Du H, Zhang M, Liu K, Liu H, Xie H, Zhang X, Si C (2020) Bacterial cellulose-based composite scaffolds for biomedical applications: a review. ACS Sustain Chem Eng 8:7536-7562. https://doi.org/10.1021/acssuschemeng.0c00125

40. Du H, Zhang M, Liu K, Parit M, Jiang Z, Zhang X, Li B, Si C (2022) Conductive PEDOT:PSS/cellulose nanofibril paper electrodes for flexible supercapacitors with superior areal capacitance and cycling stability. Chem Eng J 428:131994. https://doi.org/ 10.1016/j.cej.2021.131994

41. Du H, Parit M, Liu K, Zhang M, Jiang Z, Huang T, Zhang X, Si C (2021) Multifunctional cellulose nanopaper with superior water-resistant, conductive, and antibacterial properties functionalized with chitosan and polypyrrole. ACS Appl Mater Interface 13(27):32115-32125. https://doi.org/10.1021/acsami.1c06647

42. Basivi PK, Ramesh S, Kakani V, Yadav HM, Bathula C, Afsar N, Sivasamy A, Kim HS, Pasupuleti VR, Lee H (2021) Ultrasonication-mediated nitrogen-doped multiwalled carbon nanotubes involving carboxy methylcellulose composite for solid-state supercapacitor applications. Sci Rep 11:9918. https:// doi.org/10.1038/s41598-021-89430-x

43. Zhang M, Du H, Liu K, Nie S, Xu T, Zhang X, Si C (2021) Fabrication and applications of cellulose-based nanogenerators. Adv Compos Hybrid Mater. https://doi.org/10.1007/ s42114-021-00312-2

44. Choi ES, Kim HC, Muthoka RM, Panicker PS, Agumba DO, Kim J (2021) Aligned cellulose nanofiber composite made with electrospinning of cellulose nanofiber-polyvinyl alcohol and its vibration energy harvesting. Compos Sci Technol 209. https:// doi.org/10.1016/j.compscitech.2021.108795

45. Liu S, Du H, Liu K, Ma M, Kwon YE, Si C, Ji X, Choi SE, Zhang X (2021) Flexible and porous $\mathrm{Co}_{3} \mathrm{O}_{4}$-carbon nanofibers as binder-free electrodes for supercapacitors. Adv Compos Hybrid Mater. https://doi.org/10.1007/s42114-021-00344-8

46. Hu L, Du H, Liu C, Zhang Y, Yu G, Zhang X, Si C, Li B, Peng H (2019) Comparative evaluation of the efficient conversion of corn husk filament and corn husk powder to valuable materials via a sustainable and clean biorefinery process. ACS Sustain Chem Eng 7:1327-1336. https://doi.org/10.1021/acssuschemeng.8b05017

47. Xu R, Liu K, Du H, Liu H, Cao X, Zhao X, Qu G, Li X, Li B, Si CL (2020) Falling leaves return to their roots: a review on the preparation of $\gamma$-valerolactone from lignocellulose and its application in the conversion of lignocellulose. Chemsuschem 13:6461-6476. https://doi.org/10.1002/cssc.202002008

48. Li X, Xu R, Yang J, Nie S, Liu D, Liu Y, Si C (2019) Production of 5-hydroxymethylfurfural and levulinic acid from lignocellulosic biomass and catalytic upgradation. Ind Crop Prod 130:184197. https://doi.org/10.1016/j.indcrop.2018.12.082

49. Si C, Liu Z, Kim J, Bae YS (2008) Structure elucidation of phenylethanoid glycosides from Paulownia tomentosa Steud. var. tomentosa wood. Holzforschung 62(2):197-200. https://doi.org/ 10.1515/HF.2008.047

50. Si C, Kim JK, Bae YS, Li S (2009) Phenolic compounds in the leaves of Populus ussuriensis and their antioxidant activities. Planta Med 75(10):1165-1167. https://doi.org/10.1055/s-0029-1185476

51. Si C, Jiang J, Liu S, Hu H, Ren X, Yu G, Yu G (2013) A new lignan glycoside and phenolics from the branch wood of Pinus banksiana Lambert. Holzforschung 67(4):357-363. https://doi. org/10.1515/hf-2012-0137

52. Li X, Lu X, Nie S, Wang M, Yu Z, Duan B, Yang J, Xu R, Lu L, $\mathrm{Si} \mathrm{C}$ (2020) Efficient catalytic production of biomass-derived levulinic acid over phosphotungstic acid in deep eutectic solvent. Ind Crop Prod 145:112154. https://doi.org/10.1016/j.indcrop.2020. 112154

53. Hu Y, Yan B, Chen Z, Wang L, Tang W, Huang C (2021) Recent technologies for the extraction and separation of polyphenols in different plants: a review. J renew Mater https://doi.org/10.32604/ jrm.2022.018811 
54. Yang J, Si C, Liu K, Liu H, Li X, Liang M (2020) Production of levulinic acid from lignocellulosic biomass and application. J Forest Eng 5(5):21-27. https://doi.org/10.13360/j.issn.20961359.201905013

55. Deng W, Zhang Q, Wang Y (2014) Catalytic transformations of cellulose and cellulose-derived carbohydrates into organic acids. Catal Today 234:31-41. https://doi.org/10.1016/j.cattod.2013.12.041

56. Gómez Millán G, Hellsten S, Llorca J, Luque R, Sixta H, Balu AM (2019) Recent advances in the catalytic production of platform chemicals from holocellulosic biomass. ChemCatChem 11:2022-2042. https://doi.org/10.1002/cctc.201801843

57. Ma C, Ma M, Si C, Ji X, Wan P (2021) Flexible MXene-based composites for wearable devices. Adv Funct Mater 31:2009524. https://doi.org/10.1002/adfm.202009524

58. Ma C, Yuan Q, Du H, Ma M, Si C, Wan P (2020) Multiresponsive MXene $\left(\mathrm{Ti}_{3} \mathrm{C}_{2} \mathrm{~T}_{\mathrm{x}}\right)$-decorated textiles for wearable thermal management and human motion monitoring. ACS Appl Mater Inter 12:34226-34234. https://doi.org/10.1021/acsami.0c10750

59. Khouaja A, Koubaa A, Daly HB (2021) Dielectric properties and thermal stability of cellulose high-density polyethylene bio-based composites. Ind Crop Prod 171. https://doi.org/10.1016/j.indcrop. 2021.113928

60. Yang J, Si C, Liu K, Liu H, Li X, Liang M (2020) Production of levulinic acid from lignocellulosic biomass and application. J Forest Eng 5(5):21-27. https://doi.org/10.13360/j.issn.20961359.201906002

61. Huang X, Liu X, Jia Z, Wang B, Wu X, Wu G (2021) Synthesis of $3 \mathrm{D}$ cerium oxide/porous carbon for enhanced electromagnetic wave absorption performance. Adv Compos Hybrid Mater. https://doi.org/10.1007/s42114-021-00304-2

62. Clarkson CM, El Awad Azrak SM, Forti ES, Schueneman GT, Moon RJ, Youngblood JP (2021) Recent developments in cellulose nanomaterial composites. Adv Mater 33:2000718. https:// doi.org/10.1002/adma.202000718

63. Dong Y, Zhu X, Pan F, Deng B, Liu Z, Zhang X, Huang C, Xiang Z, Lu W (2021) Mace-like carbon fiber/ZnO nanorod composite derived from Typha orientalis for lightweight and high-efficient electromagnetic wave absorber. Adv Compos Hybrid Mater. https://doi.org/10.1007/s42114-021-00277-2

64. Rahbar Shamskar K, Heidari H, Rashidi A (2016) Preparation and evaluation of nanocrystalline cellulose aerogels from raw cotton and cotton stalk. Ind Crop Prod 93:203-211. https://doi. org/10.1016/j.indcrop.2016.01.044

65. Hou X, Zhang L, Wizi J, Liao X, Ma B, Yang Y (2017) Preparation and properties of cotton stalk bark fibers using combined steam explosion and laccase treatment. J Appl Polym Sci 134. https://doi.org/10.1002/app.45058

66. Liu R, Long L, Sheng Y, Xu J, Qiu H, Li X, Wang Y, Wu H (2019) Preparation of a kind of novel sustainable mycelium/cotton stalk composites and effects of pressing temperature on the properties. Ind Crop Prod 141. https://doi.org/10.1016/j.indcrop. 2019.111732

67. Cao Z, Zhang S, Wang C, Jiang F, Huang X, Li H, Zhang Y, Lyu $J$ (2018) Investigation on the physical properties of the charcoal briquettes prepared from wood sawdust and cotton stalk. Energy Sources, Energ Source Part A 41:493-500. https://doi.org/10. 1080/15567036.2018.1520332

68. Pan Y, Tursun Y, Abduhani H, Turap Y, Abulizi A, Talifua D (2020) Chemical looping gasification of cotton stalk with bimetallic $\mathrm{Cu} / \mathrm{Ni} /$ olivine as oxygen carrier. Int J Energ Res 44:72687282. https://doi.org/10.1002/er.5439

69. Uyan M, Alptekin FM, Bastabak B, Ozgul S, Erdogan B, Ogut TC, Sezer U, Celiktas MS (2019) Combined biofuel production from cotton stalk and seed with a biorefinery approach. Biomass Convers Bior 10:393-400. https://doi.org/10.1007/s13399-019-00427-z
70. Tian X, Ma H, Li Z, Yan S, Ma L, Yu F, Wang G, Guo X, Ma Y, Wong C (2017) Flute type micropores activated carbon from cotton stalk for high performance supercapacitors. J Power Sources 359:88-96. https://doi.org/10.1016/j.jpowsour.2017.05.054

71. Ingram G, Nawrath C (2017) The roles of the cuticle in plant development: organ adhesions and beyond. J Exp Bot 68:53075321. https://doi.org/10.1093/jxb/erx313

72. Du H, Liu C, Zhang Y, Yu G, Si C, Li B (2016) Preparation and characterization of functional cellulose nanofibrils via formic acid hydrolysis pretreatment and the followed high-pressure homogenization. Ind Crop Prod 94:736-745. https://doi.org/10. 1016/j.indcrop.2016.09.059

73. Liu W, Du H, Liu H, Xie H, Xu T, Zhao X, Liu Y, Zhang X, Si C (2020) Highly efficient and sustainable preparation of carboxylic and thermostable cellulose nanocrystals via $\mathrm{FeCl}_{3}$-catalyzed innocuous citric acid hydrolysis. ACS Sustain Chem Eng 8:16691-16700. https://doi.org/10.1021/acssuschemeng.0c06561

74. Yang X, Xie H, Du H, Zhang X, Zou Z, Zou Y, Liu W, Lan H, Zhang X, Si C (2019) Facile extraction of thermally stable and dispersible cellulose nanocrystals with high yield via a green and recyclable $\mathrm{FeCl}_{3}$-catalyzed deep eutectic solvent system. ACS Sustain Chem Eng 7:7200-7208. https://doi.org/10.1021/acssuschemeng.9b00209

75. Liu W, Du H, Liu K, Liu H, Xie H, Si C, Pang B, Zhang X (2021) Sustainable preparation of cellulose nanofibrils via choline chloride-citric acid deep eutectic solvent pretreatment combined with high-pressure homogenization. Carbohyd Polym 267:118220. https://doi.org/10.1016/j.carbpol.2021.118220

76. Xie H, Zou Z, Du H, Zhang X, Wang X, Yang X, Wang H, Li G, Li L, Si C (2019) Preparation of thermally stable and surfacefunctionalized cellulose nanocrystals via mixed $\mathrm{H}_{2} \mathrm{SO}_{4} /$ oxalic acid hydrolysis. Carbohyd Polym 223:115116. https://doi.org/ 10.1016/j.carbpol.2019.115116

77. Wang H, Du H, Liu K, Liu H, Xu T, Zhang S, Chen X, Zhang R, Li H, Xie H, Zhang X, Si C (2021) Sustainable preparation of bifunctional cellulose nanocrystals via mixed $\mathrm{H}_{2} \mathrm{SO}_{4}$ /formic acid hydrolysis. Carbohyd Polym 266:118107. https://doi.org/10. 1016/j.carbpol.2021.118107

78. Wang H, Xie H, Du H, Wang X, Liu W, Duan Y, Zhang X, Sun L, Zhang X, Si C (2020) Highly efficient preparation of functional and thermostable cellulose nanocrystals via $\mathrm{H}_{2} \mathrm{SO}_{4}$ intensified acetic acid hydrolysis. Carbohyd Polym 239:116233. https://doi. org/10.1016/j.carbpol.2020.116233

79. Zhu E, Xu G, Sun S, Yang J, Yang H, Wang D, Guo Z, Shi Z, Deng J (2021) Rosin acid modification of bamboo powder and thermoplasticity of its products based on hydrothermal pretreatment. Adv Compos Hybrid Mater 4:584-590. https://doi.org/10. 1007/s42114-021-00266-5

80. Meng F, Wang D (2020) Effects of vacuum freeze drying pretreatment on biomass and biochar properties. Renew Energ 155:1-9. https://doi.org/10.1016/j.renene.2020.03.113

81. Xu R, Si C, Kong F, Li X (2020) Synthesis of $\gamma$-valerolactone and its application in biomass conversion. J Forest Eng 5(2):20-28. https://doi.org/10.13360/j.issn.2096-1359.201904004

82. Amini N, Dwivedi S, Ahmad W, Haritos VS, Tanksale A (2021) Polar solvents enhance the efficiency of microwave pre-treatment of woody biomass. Biomass Bioenerg 155. https://doi.org/10. 1016/j.biombioe.2021.106281

83. Zhu E, Xu G, Ye X, Yang J, Yang H, Wang D, Shi Z, Deng J (2021) Preparation and characterization of hydrothermally pretreated bamboo powder with improved thermoplasticity by propargyl bromide modification in a heterogeneous system. Adv Compos Hybrid Mater. https://doi.org/10.1007/ s42114-021-00316-y

84. Reddy N, Yang Y (2009) Properties and potential applications of natural cellulose fibers from the bark of cotton stalks. Bioresour 
Technol 100:3563-3569. https://doi.org/10.1016/j.biortech.2009. 02.047

85. Bhati N, Shreya SA (2020) Cost-effective cellulase production, improvement strategies, and future challenges. J Food Process Eng 44. https://doi.org/10.1111/jfpe.13623

86. Jin Y, Chen H, Wu W, Wei W (2020) Investigations of the effect of water-soluble lignin on enzymatic hydrolysis of lignocellulose. J Forest Eng 5(4):12-19. https://doi.org/10.13360/j.issn.20961359.201909026

87. Akbarpour I, Ghasemian A, Resalati H, Saraeian A (2018) Biodeinking of mixed ONP and OMG waste papers with cellulase. Cellulose 25:1265-1280. https://doi.org/10.1007/ s10570-017-1641-y

88. Jiang H, Zhang Y, Wang X (2009) Effect of lipases on the surface properties of wheat straw. Ind Crop Prod 30:304-310. https://doi. org/10.1016/j.indcrop.2009.05.009

89. Sachan A, Choudhary V, Vimal KK, Kapur GS (2018) Chemical treatment of cotton stalk and its effects on mechanical, rheological and morphological properties of polypropylene/cotton stalk bio-composites. Polym Composite 39:286-296. https://doi.org/ $10.1002 / \mathrm{pc} .24435$

90. Du S, Su X, Yang W, Wang Y, Kuang M, Ma L, Fang D, Zhou D (2016) Enzymatic saccharification of high pressure assist-alkali pretreated cotton stalk and structural characterization. Carbohydr Polym 140:279-286. https://doi.org/10.1016/j.carbpol.2015.12. 056

91. Hemansi, Kaushik A, Yadav G, Saini JK (2021) Simultaneous saccharification and fermentation of sequential dilute acid-alkali pretreated cotton (Gossypium hirsutum L.) stalk for cellulosic ethanol production. J Chem Technol Biot. https://doi.org/10. 1002/jctb. 6723

92. Zikeli F, Vinciguerra V, D'annibale A, Capitani D, Romagnoli M, Scarascia Mugnozza G (2019) Preparation of lignin nanoparticles from wood waste for wood surface treatment. Nanomaterials (Basel) 9. https://doi.org/10.3390/nano9020281

93. Kyziol L (2016) Reinforcing wood by surface modification. Compos Struct 158:64-71. https://doi.org/10.1016/j.compstruct.2016. 06.055

94. Yuan B, Guo M, Murugadoss V, Song G, Guo Z (2021) Immobilization of graphitic carbon nitride on wood surface via chemical crosslinking method for UV resistance and self-cleaning. Adv Compos Hybrid Mater 4:286-293. https://doi.org/10.1007/ s42114-021-00235-y

95. Teng T, Duan A, Zhang Y (2020) The trial production of unbleached paper towel using bio-oxidation mechanical cotton stalk pulp. China Pulp Paper. https://doi.org/10.11980/j.issn. 0254-508X.2017.05.014

96. Xie W, Zhou D, Ren Y, Tang S, Kuang M, Du SK (2018) 1-Butyl-3-methylimidazolium chloride pretreatment of cotton stalk and structure characterization. Renew Energ 125:668-674. https://doi.org/10.1016/j.renene.2018.03.011

97. Yang G, Jahan MS, Liu H, Ni Y (2012) Acid hydrolysis of prehydrolysis liquor produced from the kraft-based dissolving pulp production process. Ind Eng Chem Res 51:13902-13907. https:// doi.org/10.1021/ie3023059

98. Yan J, Yu Y, Wang C, Cai W, Wu L, Yang Y, Zhang H (2021) Production, physicochemical characteristics, and in vitro biological activities of polysaccharides obtained from fresh bitter gourd (Momordica charantia L.) via room temperature extraction techniques. Food Chem 337:127798. https://doi.org/10.1016/j. foodchem. 2020.127798

99. Sadeghifar H, Ragauskas A (2020) Perspective on technical lignin fractionation. ACS Sustain Chem Eng 8:8086-8101. https://doi.org/10.1021/acssuschemeng.0c01348

100. Ko C, Yang C, Chang F, Lin L (2019) Effect of Paenibacillus cellulase pretreatment for fiber surface. J Environ Manage 241:1-11. https://doi.org/10.1016/j.jenvman.2019.03.133

101. Bidlack J, Malone M, Benson R (1992) Molecular structure and component integration of secondary cell walls in plants. Proceedings of the Oklahoma Academy of Science, USA

102. Scheller H, Ulvskov P (2010) Hemicelluloses. Annu Rev Plant Biol 61:263-289. https://doi.org/10.1146/annurev-arplant-042809-112315

103. Martinez AT, Ruiz-Duenas FJ, Martinez MJ, Del Rio JC, Gutierrez A (2009) Enzymatic delignification of plant cell wall: from nature to mill. Curr Opin Biotechnol 20:348-357. https://doi.org/10.1016/j. copbio.2009.05.002

104. Lampugnani ER, Khan GA, Somssich M, Persson S (2018) Building a plant cell wall at a glance. J Cell Sci 131. https://doi. org/10.1242/jcs. 207373

105. Chundawat SPS, Donohoe BS, da Costa SL, Elder T, Agarwal UP, Lu F, Ralph J, Himmel ME, Balan V, Dale BE (2011) Multi-scale visualization and characterization of lignocellulosic plant cell wall deconstruction during thermochemical pretreatment. Energ Environ Sci 4. https://doi.org/10.1039/c0ee00574f

106. Du S, Zhu X, Wang H, Zhou D, Yang W, Xu H (2013) High pressure assist-alkali pretreatment of cotton stalk and physiochemical characterization of biomass. Bioresour Technol 148:494-500. https://doi.org/10.1016/j.biortech.2013.09.020

107. Wang G, Zhang S, Xu W, Qi W, Yan Y, Xu Q (2015) Efficient saccharification by pretreatment of bagasse pith with ionic liquid and acid solutions simultaneously. Energ Convers Manage 89:120-126. https://doi.org/10.1016/j.enconman.2014.09.029

108. Debona D, Rodrigues FA, Datnoff LE (2017) Silicon's role in abiotic and biotic plant stresses. Annu Rev Phytopathol 55:85107. https://doi.org/10.1146/annurev-phyto-080516-035312

109. Kocaefe D, Huang X, Kocaefe Y, Boluk Y (2013) Quantitative characterization of chemical degradation of heat-treated wood surfaces during artificial weathering using XPS. Surf Interface Anal 45:639-649. https://doi.org/10.1002/sia.5104

110. Bañuls-Ciscar J, Pratelli D, Abel ML, Watts JF (2016) Surface characterisation of pine wood by XPS. Surf Interface Anal 48:589-592. https://doi.org/10.1002/sia.5960

111. Bertaud F, Holmbom B (2004) Chemical composition of earlywood and latewood in Norway spruce heartwood, sapwood and transition zone wood. Wood Sci Technol 38:245-256. https://doi. org/10.1007/s00226-004-0241-9

112. Li Y, Tong S, Li R, Dai L, Si, C (2021) Preparation and properties of Fe/lignin nanoparticle composite paper. J For Eng 6(06):123129. https://doi.org/10.13360/j.issn.2096-1359.202106021

Publisher's Note Springer Nature remains neutral with regard to jurisdictional claims in published maps and institutional affiliations. 